\title{
The anti-bacterial iron-restriction defence mechanisms of egg white; the potential role of three lipocalin-like proteins in resistance against Salmonella
}

\author{
Louis Alex Julien (D) Florence Baron • Sylvie Bonnassie • Françoise Nau • \\ Catherine Guérin - Sophie Jan · Simon Colin Andrews
}

Received: 19 January 2019/Accepted: 25 January 2019/Published online: 27 February 2019

(C) The Author(s) 2019

\begin{abstract}
Salmonella enterica serovar Enteritidis $(\mathrm{SE})$ is the most frequently-detected Salmonella in foodborne outbreaks in the European Union. Among such outbreaks, egg and egg products were identified as the most common vehicles of infection. Possibly, the major antibacterial property of egg white is iron restriction, which results from the presence of the ironbinding protein, ovotransferrin. To circumvent iron restriction, $S E$ synthesise catecholate siderophores (i.e. enterobactin and salmochelin) that can chelate iron from host iron-binding proteins. Here, we highlight the role of lipocalin-like proteins found in egg white that could enhance egg-white iron restriction through sequestration of certain siderophores, including enterobactin. Indeed, it is now apparent that the egg-white lipocalin, Ex-FABP, can inhibit bacterial growth via its siderophore-binding capacity in vitro. However, it remains unclear whether Ex-FABP performs such a function in egg white or during bird
\end{abstract}

L. A. Julien · S. C. Andrews ( $\square)$

School of Biological Sciences, University of Reading, Reading RG6 6UA, UK

e-mail: s.c.andrews@reading.ac.uk

L. A. Julien · F. Baron - S. Bonnassie .

F. Nau · C. Guérin · S. Jan

UMR1253 Sciences et Technologie du Lait et de l'œuf,

Agrocampus-Ouest/INRA, 35042 Rennes, France

S. Bonnassie

Université de Rennes I, Rennes, France infection. Regarding the two other lipocalins of egg white (Cal- $\gamma$ and $\alpha-1$-glycoprotein), there is currently no evidence to indicate that they sequester siderophores.

Keywords Salmonella Enteritidis - Salmochelin · Enterobactin · Ex-FABP · Cal- $\gamma \cdot$ Alpha-1ovoglycoprotein

\section{Survival of Salmonella within egg white and the role of iron restriction}

The powerful antibacterial defence mechanisms of egg white

In the EU, Salmonella enterica is the bacterium most frequently (93\%) detected in egg white, with $S$. enterica serovar Enteriditis ( $S E$ ) being the major $(67 \%)$ strain associated with outbreaks caused by eggs and egg products (EFSA 2014). Thus, $S E$ appears to be very well suited to infection of, and survival within, eggs (Clavijo et al. 2006; Vylder et al. 2013; Gantois et al. 2008). Egg white is noted for its strong antimicrobial activity which indicates that $S E$ has powerful egg-white resistance mechanisms. Indeed, the various antimicrobial activities exhibited by egg white can be considered to present a unique set of challenges for bacterial invaders. These include physico-chemical factors, in particular high $\mathrm{pH}$ 
(inhibiting growth; Sharp and Whitaker 1927) and high viscosity (limiting motility; Schneider and Doetsch 1974; Yadav and Vadehra 1977); in addition, high osmolarity (causing osmotic stress) has been suggested (Clavijo et al. 2006). The $\mathrm{pH}$ of egg white shifts from $\sim 7.6$ (upon oviposition) to 9.3 (a few days later) as a result of $\mathrm{CO}_{2}$ release (Sharp and Powell 1931). The viscosity of egg white (with a shear rate of $400 \mathrm{~s}^{-1}: 5 \mathrm{mPa} . \mathrm{s}^{-1}$ at $20^{\circ} \mathrm{C}$; Lang and Rha 1982) is mainly caused by the presence of ovomucin, a glycoprotein contributing $3.5 \% \mathrm{w} / \mathrm{w}$ of the total egg albumin protein (egg white has a total protein content of $\sim 10 \%$ w/w; Kovacs-Nolan et al. 2005).

In addition to these physico-chemical factors, egg white possesses an array of proteins that provide further defence against pathogens [see review by Baron et al. (2016) for more detail], notably:

- ovotransferrin (oTf), involved in iron deprivation (Garibaldi 1970) and bacterial membrane damage (Aguilera et al. 2003);

- lysozyme (Derde et al. 2013) and defensins (Hervé-Grépinet et al. 2010; Gong et al. 2010), that would be expected to disrupt bacterial membrane integrity;

- ovalbumin X, a heparin-binding protein exhibiting antimicrobial activity (Réhault-Godbert et al. 2013);

- ovostatin (Nagase et al. 1983) and cystatin (Wesierska et al. 2005), presumed to inhibit exogenous proteases; and

- avidin (Banks et al. 1986), a biotin sequestration protein.

The major role of iron restriction

and ovotransferrin in egg-white defence

It is generally accepted that the major factor limiting bacterial growth in egg white is iron restriction. This results from the presence of oTf, a powerful ironbinding protein (Garibaldi 1970; Lock and Board 1992; Baron et al. 1997). The iron restriction of egg white was first discovered by Schade and Caroline (1944) who found that exposure to egg white inhibits the growth of Shigella dysenteriae. Among 31 growth factors added to egg white, only iron overcame the observed egg white-imposed growth inhibition. Two years later, Alderton et al. (1946) identified the eggwhite factor responsible as 'conalbumin', which is now known to be a member of the transferrin family and is more commonly referred as oTf. Since these early studies, subsequent work has confirmed the role of oTf as an egg-white iron-restriction agent preventing growth of a range of microbial species, including Salmonella (Schade and Caroline 1944; Valenti et al. 1983, 1985; Ibrahim 1997; Baron et al. 1997, 2000). Indeed, iron-acquisition mutants of $S E$ display decreased survival and/or growth in egg white (Kang et al. 2006). Such studies confirm the antibacterial role of iron restriction in egg white. A recent global transcriptomic study (Baron et al. 2017) revealed a major iron-starvation response of $S E$ upon exposure to egg white which was caused by relief of Fur- (the global transcriptional regulator of iron-dependent gene expression; Rabsch et al. 2003) mediated repression. Likewise, a quantitative proteomic analysis (isobaric tags for relative and absolute quantitation; iTRAQ) showed that iron-acquisition-system-related proteins are induced by egg white (Qin et al. 2019). These findings confirm that $S E$ suffers from iron limitation in egg white. The low iron availability in egg white exerts a strong bacteriostatic influence (Bullen et al. 1978; Baron et al. 1997) because iron is essential for growth of nearly all organisms, including bacteria (Andrews et al. 2003). In many ways, the antibacterial iron-restriction strategy of egg white is comparable to the iron-dependent 'nutritional immunity' defence mechanisms observed in mammals, where serum transferrin maintains concentrations of extracellular free iron at levels $\left(10^{-18} \mathrm{M}\right)$ well below those that support bacterial growth (Bullen et al. 2005).

OTf is believed to be the critical iron-restriction component in egg white. Like other members of the transferrin family, its structure consists of two 'lobes', each with a strong affinity for a single $\mathrm{Fe}^{3+}$ ion (apparent binding constant of around $10^{32} \mathrm{M}^{-1}$, with of $1.5 \times 10^{18} \mathrm{M}^{-1}$ and $1.5 \times 10^{14} \mathrm{M}^{-1}$ for the $\mathrm{C}$ - and $\mathrm{N}$-terminal lobes, respectively, at $\mathrm{pH}$ 7.5; GuhaThakurta et al. 2003; Chart 1993; Schneider et al. 1984). The iron-restriction-based bacteriostatic activity of oTf is enhanced by bicarbonate (which is likely related to the apparent dependence of metal binding on the presence of a suitable anion; Valenti et al. 1983) and high pH (Valenti et al. 1981; Antonini et al. 1977; Lin et al. 1994). Interestingly, egg white contains levels of iron $(\sim 0.1 \mathrm{mg}$ iron per $100 \mathrm{~g}$ which is equivalent to $\sim 18 \mu \mathrm{M}$; USDA 2010; Nys and 
Sauveur 2004) that would normally be sufficient for bacterial growth. However, oTf is present in such high abundance in egg white $(170 \mu \mathrm{M} ; 13 \%$ of total protein content, second most abundant egg white protein after ovalbumin; Sauveur 1988) that oTf iron-binding capacity exceeds iron availability by 17 -fold. Since egg white is aerobic and has a high $\mathrm{pH}$ (after laying), iron in egg white would be expected to be largely in the ferric state (the form bound by oTf) so it can be assumed that virtually all iron in egg white is bound to oTf such that very little is freely available (Sauveur 1988). However, some bacteria are more susceptible to growth inhibition by oTf than others. Indeed, in vitro studies showed that the most sensitive species are Pseudomonas and Escherichia coli, and the most resistant are Staphylococcus aureus, Proteus and Klebsiella (Valenti et al. 1983). Unsurprisingly, the effects of oTf can be relieved by iron-mobilising agents (e.g. citrate) (Valenti et al. 1983). OTf also appears to possess additional antibacterial activities since its effects are diminished when separated from direct contact with bacteria through location in a dialysis bag or immobilisation on beads (Valenti et al. 1985). Indeed, it has been shown that oTf can partially penetrate and permeabilise bacterial membranes, acting as an uncoupling agent (Aguilera et al. 2003). This activity is likely related to the presence of a Cysrich antibacterial-peptide-like motif located on the surface of the oTf molecule which confers the ability to kill Gram-negative bacteria (Ibrahim et al. 1998, 2000).

\section{Iron acquisition by Salmonella}

The role of the two siderophores of Salmonella in iron uptake and pathogenicity

The most important mechanism used by bacteria to circumvent iron restriction involves the synthesis of siderophores that bind exogenous ferric iron with high affinity and specificity, and enable acquisition of iron from host sources (Andrews et al. 2003). The siderophores employed by Salmonella are catecholates called enterobactin (or enterochelin) and salmochelin. Enterobactin was first identified in E. coli (O'Brien and Gibson 1970) and Salmonella Typhimurium (ST) (Pollack and Neilands 1970). Although enterobactin synthesis was shown to be required for survival of $S \mathrm{~T}$ in low-iron in vitro environments (Pollack et al. 1970), its role in pathogenesis is limited for reasons that were, initially, unclear (Benjamin et al. 1985; Rabsch et al. 2003). Salmochelin (which is closely similar to enterobactin) was not identified until more than three decades after enterobactin when it was found to be a product of pathogenic enterobacteria, such as Salmonella (Hantke et al. 2003). It was designated 'salmochelin' as it appeared at first to be a characteristic of Salmonella strains. However, salmochelins have now been reported in avian pathogenic E. coli (APEC), uropathogenic E. coli (UPEC), ST and Klebsiella pneumoniae where they contribute to virulence (Caza et al. 2008; Gao et al. 2012; Crouch et al. 2008; Bachman et al. 2012). It should be noted that the ferrous-iron transport systems of Salmonella (FeoABC and SitABCD) can also contribute to pathogenicity and/or gut colonisation (see review by Carpenter and Payne 2014).

Enterobactin: a powerful siderophore, but with limited effect in vivo

Enterobactin is a serine macrotrilactone (Fig. 1) that has a far higher affinity for iron than oTf (formation constants of $10^{52}$ and $10^{32} \mathrm{M}^{-1}$, respectively), which allows siderophore-producing bacteria to use oTf as a source of iron (Chart 1993). Although the metabolism of enterobactin is best studied in E. coli, Salmonella possesses a highly similar set of enterobactin-related genes which are assumed to play similar roles. The enterobactin precursor, 2,3-dihydroxybenzoate (DHB), is synthesized from chorismate by enzymes encoded by the ent $C$, ent $B$ and $e n t A$ genes. In a second step, DHB and serine are combined, polymerized and cyclized to form enterobactin by enzymes encoded by the entE, entB and entF genes (Gehring et al. 1998). EntS is required for enterobactin export through the cytosolic membrane (Furrer et al. 2002) whereas TolC is involved in enterobactin efflux across the outer membrane (Bleuel et al. 2005) (Fig. 2). Once complexed with ferric iron, uptake of ferric-enterobactin into the periplasm is mediated by the iron-regulated outer-membrane proteins, FepA and Cir (and IroN in Salmonella) (Rabsch et al. 1999, 2003); the energytransducing TonB-ExbBD complex is also required for this step (Skare et al. 1993; Fig. 2). Ferricenterobactin is then imported into the cytoplasm by the ATP-binding cassette transporter, FepBDGC 


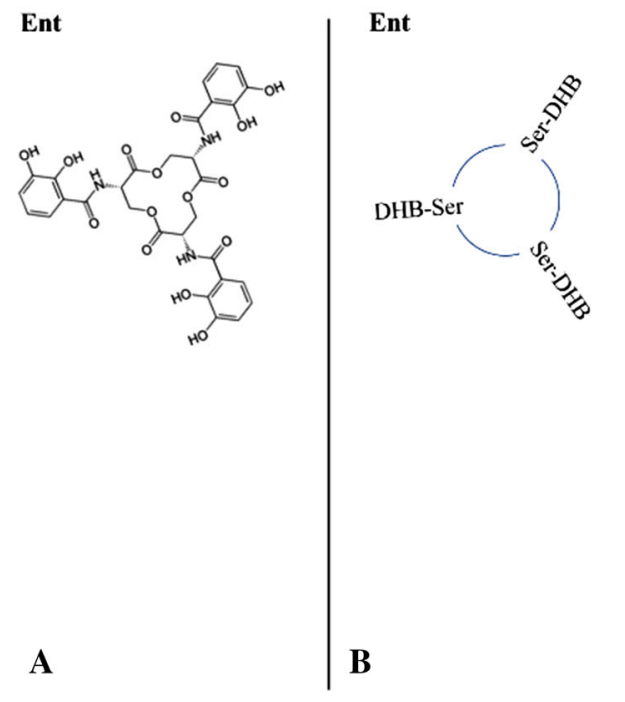

Fig. 1 Enterobactin (Ent), Salmochelin (S4) and related structures. a Structure of enterobactin. b Schematic representation of Ent, S4 and its derivatives. Salmochelin S4 and S2 are both di-glucosylated forms of enterobactin (DGEnt) but the latter is linear. MGEnt is a 2,3-dihydroxybenzoyl serine

(Langman et al. 1972; Chenault and Earhart 1992). Finally, the imported ferric-enterobactin complex is processed by the Fes esterase which cleaves the cyclic ring of the siderophore, lowering affinity for the bound iron which enables dissociation (O'Brien et al. 1971).

Despite its high affinity for iron, enterobactin is not as effective as other siderophores in vivo (Konopka et al. 1982; Montgomerie et al. 1984), and this poor performance appears to be related to its rapid clearance from the serum (Konopka and Neilands 1984). An unknown factor in serum was found to impede transfer of iron from transferrin to enterobactin, and from ${ }^{55} \mathrm{Fe}$-enterobactin to E. coli (Konopka and Neilands 1984). However, serum has little impact on iron chelation by the aerobactin siderophore (Konopka and Neilands 1984). Aerobactin was also shown to provide a significant selective advantage for E. coli growth in vitro (Williams and Carbonetti 1986), and in a cutaneous infection model (Demir and Kaleli 2004), even though its affinity for iron is weaker than that of enterobactin (formation constants of $10^{23}$ and $10^{52} \mathrm{M}^{-1}$, respectively; Neilands, 1981). Similar findings were found for S. enterica, as enterobactin is not a virulence factor for $S \mathrm{~T}$ or $\mathrm{SE}$ in mouse and chicken infection models (Benjamin et al. 1985; Rabsch et al. 2003). Later, the serum factor responsible for limiting the action of enterobactin was macrotrilactone that is glucosylated only once. The salmochelin degradation products, S1 and SX are the mono-glucosylated dimer and monomer, respectively. Ser serine, DHB dihydroxybenzoate

identified as an acute-phase protein, called LCN2 (lipocalin 2 or neutrophil gelatinase-associated lipocalin) (Goetz et al. 2002), that previously had an unclear specific purpose. LCN2 was subsequently found to be induced and secreted in response to activation of Toll-like innate immune receptors (Flo et al. 2004), bind to enterobactin (Goetz et al. 2002) and inhibit enterobactin activity partly through rapid clearance from the serum (Devireddy et al. 2005), and thus shown to function as a 'siderocalin' (siderophorebinding lipocalin).

Salmochelin: a glucosylated siderophore, promoting Salmonella pathogenicity through LCN2 evasion

Salmochelin S4 is a diglucosyl-C enterobactin (Fig. 1). The affinity of salmochelin for $\mathrm{Fe}^{3+}$ is not reported (Valdebenito et al. 2006; Watts et al. 2012), however, it is assumed that glucosylation does not significantly impact $\mathrm{Fe}^{3+}$ ligation or affinity (Luo et al. 2006). The genetic locus responsible for this glucosylation of enterobactin in Salmonella is the iro-gene cluster (or 'iroA locus') (Hantke et al. 2003). This locus consists of two convergent transcription units: iroBCDE and iroN (Bäumler et al. 1998). Salmochelin synthesis involves the di-glucosylation of enterobactin 


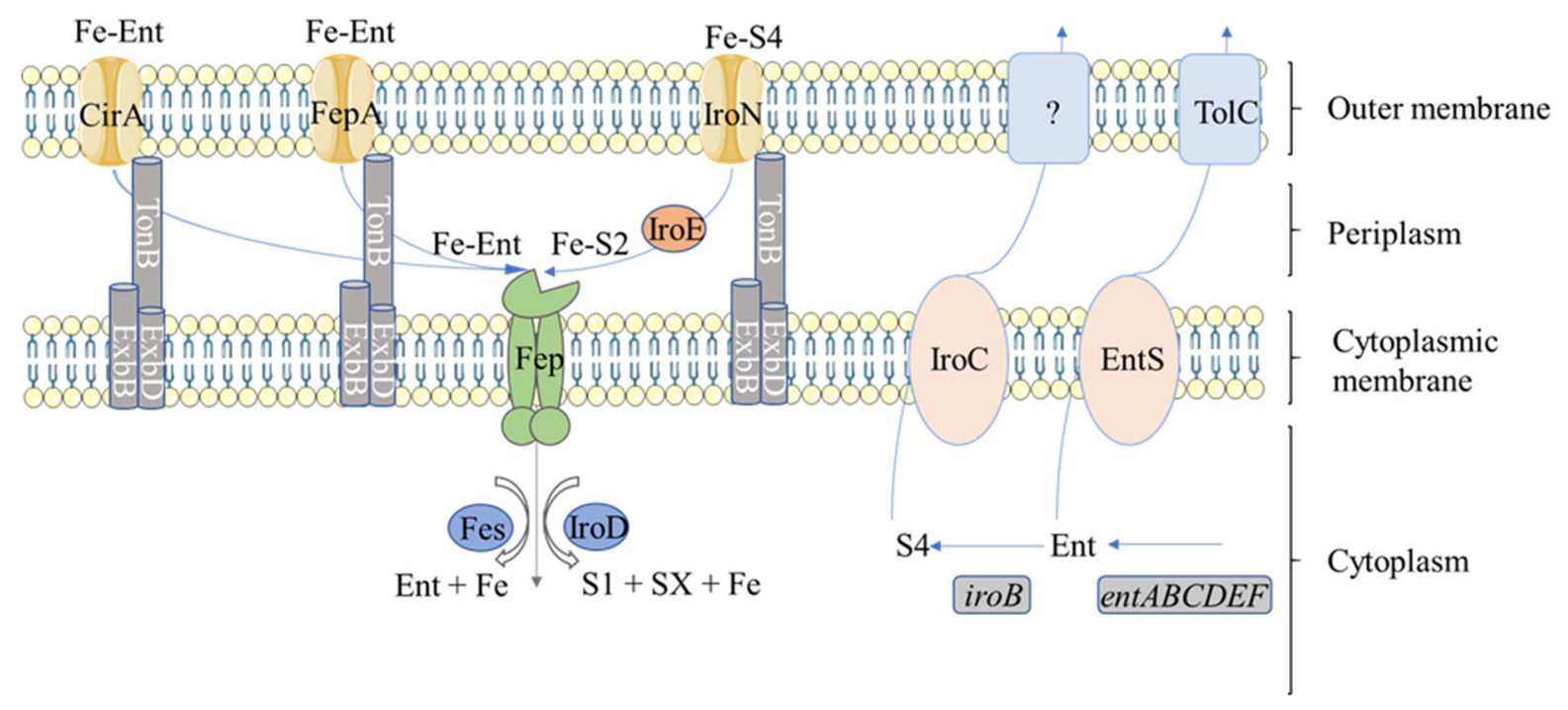

Fig. 2 Summary of synthesis, export, import and utilisation, of enterobactin and salmochelin. Enterobactin (synthesised by EntABCDEF) is mono or di-glucosylated by IroB. Enterobactin is exported from the cytoplasm by EntS whereas salmochelin is exported by IroC. TolC is then involved in enterobactin efflux across the outer membrane. Once complexed with ferric iron, ferri-salmochelin is taken up across the outer membrane via IroN and is then linearized to the $\mathrm{S} 2$ form by the periplasm IroE esterase, whereas ferri-enterobactin is taken up via CirA, or

into S4 in a step catalysed by the glucosyltransferase, IroB (Bister et al. 2004); the resulting salmochelin is then exported across the cytosolic membrane by IroC (Crouch et al. 2008; Fig. 2). Once complexed with ferric iron, ferric-salmochelin is taken up across the outer membrane via IroN (Hantke et al. 2003) and is subsequently linearized to the $\mathrm{S} 2$ form by the periplasm IroE esterase (Lin et al. 2005; Zhu et al. 2005). The $\mathrm{S} 2$ form is then transported into the cytoplasm via FepBCDG (which also imports enterobactin) (Crouch et al. 2008). The imported S2 salmochelin is further esterified by IroD into monomeric and/or dimeric forms, which is presumed to facilitate iron release (Lin et al. 2005; Zhu et al. 2005). The resulting degradation products, S1 and SX (monoglucosylated dimer and monomer, respectively), are exported from the cytoplasm into the medium where they potentially contribute to iron acquisition (Lin et al. 2005; Zhu et al. 2005). Initially, the reason for the glucosylation of enterobactin (generating salmochelin) was unclear. Subsequently, it was discovered that although LCN2 has high affinity for enterobactin $\left(\mathrm{K}_{\mathrm{d}}\right.$ of $0.41 \pm 0.11 \mathrm{nM}$ ) and its derivatives/precursors
FepA. The Fe-S2 and Fe-Ent are then transported into the cytoplasm via the FepBCDG ATP-binding cassette transporter, and are then esterified by the IroD and Fes esterases, respectively, which is presumed to facilitate iron release. The resulting salmochelin degradation products, S1 and SX, are exported from the cytoplasm into the medium. It is important to note that the Iro transport components can also assist with enterobactin utilisation

$\left(\mathrm{DHB}, \mathrm{K}_{\mathrm{d}}\right.$ of $\left.7.9 \pm 1.8 \mathrm{nM}\right)$, as well as other catecholate-type ferric siderophores (e.g. parabactin, cepabactin and carboxymycobactins; Goetz et al. 2002; Holmes et al. 2005), it does not effectively bind to salmochelin S4 (Fischbach et al. 2006; Valdebenito et al. 2007). Furthermore, the LCN2 receptor, 24p3, was shown to mediate the import of ferri-siderophorebound LCN2 into mammalian cells, removing both the iron and enterobactin from circulation (Devireddy et al. 2005). Thus, glucosylation of enterobactin is considered to be a strategy employed by pathogens to prevent siderophore sequestration and removal from circulation by LCN2.

LNC2 was originally identified as a component of neutrophil granules but is also expressed in epithelial cells in response to inflammatory signals (Kjeldsen et al. 1993). Nielsen et al. (1996) revealed that LCN2 might bind lipophilic inflammatory mediators like platelet-activating factor, leukotriene B4 and lipopolysaccharide. This led to the initial suggestion that LCN2 acts as immune-modulatory factor through transport of lipophilic molecules to inflammation sites (Goetz et al. 2000). As eluded to above, a clearer 
purpose for LCN2 became apparent when the protein was produced heterologously in E. coli and was isolated bound, surprisingly, to a red chromophore, which was subsequently identified as enterobactin (Goetz et al. 2002). This finding led to further studies demonstrating a role for LCN2 in host-pathogen interactions (Bachman et al. 2012; Fischbach et al. 2006; Flo et al. 2004). These further studies showed that the iro-gene cluster confers resistance to the growth inhibitory effects of LCN2 in vitro and that mice rapidly succumb to infection by E. coli $\mathrm{H} 9049$ harbouring the iro-gene cluster, but not its iro-free counterpart (Fischbach et al. 2006). Other studies showed that salmochelin contributes to virulence of both avian pathogenic and uropathogenic E. coli (APEC and UPEC) through its iron-binding activity (Gao et al. 2012). Indeed, salmochelin-defective mutants of APEC E058 and UPEC U17 showed significantly decreased pathogenicity compared to the wild-type strains in a chicken infection model (Gao et al. 2012). Likewise, the efficient glucosylation (IroB), transport (IroC and IroN) and processing (IroD and IroE) of salmochelins were shown to be required for APEC virulence (Caza et al. 2008). The role of glucosylation in S. enterica pathogenicity was further illustrated by the observation that the iro locus confers a competitive advantage to $S \mathrm{~T}$ in colonizing the inflamed intestine of wild-type, but not of LCN2deficient, mice (Raffatellu et al. 2009). It should be noted that the glucosylation and linearisation of enterobactin was suggested to enhance the activity of salmochelin through increasing its hydrophilic nature, which might be advantageous for iron scavenging in a membrane-rich microenvironment (Luo et al. 2006).

\section{Egg-white 'lipocalins': role in enhancing iron restriction through sequestration of bacterial siderophores?}

Evidence for the presence of lipocalin-like proteins in egg white

LCN2 belongs to the 'lipocalin superfamily' which includes a variety of proteins involved in transport of hydrophobic ligands, such as purpurin, retinol-binding protein, $\alpha$-1-glycoprotein, apolipoprotein, probasin, $\alpha$ 1-microglobulin and prostaglandin D synthetase. Although the family members display low overall sequence identity (Greene et al. 2003), lipocalins share a common three-dimensional structure characterised by an eight-stranded $\beta$-barrel (with a small C-terminal helix) that forms a chalice, at the bottom of which the hydrophobic ligand is bound (Françoise 1994). Due to their diversity, lipocalin-like proteins have various functions e.g. in immune response, pheromone transport, biological prostaglandin synthesis, retinoid binding and cancer cell interactions (Flower 1996). Lipocalins can be divided into two major subfamilies (see the Pfam database; El-Gebali et al. 2019). One subfamily (PF00061) consists of $\sim 4000$ Pfam entries that are mostly (88\%) from Metazoan species, and includes LCN2, whereas the other subfamily (PF08212) consists of $\sim 3000$ entries, mostly from $(67 \%)$ Bacteria. Lipocalins are predominantly $(92 \%)$ single domain proteins and multiple homologues are found in vertebrates (e.g. there are 37 lipocalins identified in the human genome; Du et al. 2015).

Since lipocalins are found throughout most of the living kingdom, it may not be surprising to find that they are present in egg white. Extracellular fatty-acidbinding protein (Ex-FABP) was the first lipocalin-like protein identified in egg white and was discovered by a proteomic analysis of hen egg white using 2-dimensional gel electrophoresis (2-DE) followed by liquid chromatography-mass spectroscopy (LC-MS/MS) (Desert et al. 2001). Further work by Guérin-Dubiard et al. (2006) using 2-DE, LC-MS/MS and MALDITOF identified a total of 16 proteins in hen egg white, including Ex-FABP as well as two other lipocalin-like proteins: chondrogenesis-associated lipocalin (Cal- $\gamma$ or prostaglandin D synthase) and $\alpha$-1-ovoglycoprotein. The presence of the three lipocalin-like proteins in egg white was later confirmed by further proteomic analyses involving 1-DE with LC-MS/MS, 2-DE combined with protein-enrichment (peptide ligand libraries) technology, and a dual-pressure linear-iontrap Orbitrap instrument (LTQ Orbitrap Velos) (Mann 2007; D’Ambrosio et al. 2008; Mann and Mann 2011).

Although the concentrations of the three lipocalinlike proteins have not been reported, in the GuérinDubiard et al. (2006) study the intensity of Cal- $\gamma$ and Ex-FABP 2-DE spots were weak indicating a very low concentration. In other work (Mann 2007; Mann and Mann 2011), the exponentially-modified-protein abundance index (emPAI) was used to provide an estimate of the absolute abundance of each egg-white protein, which indicated that the lipocalin-like 
proteins belong to the 'minor proteins' set (such as avidin, cystatin, apolipoprotein D, HEP21, Defensin11) rather than the 'major proteins' set (such as ovalbumin, ovotransferrin, lysozyme, ovomucoid and ovoinhibitor). However, as $\alpha$-1-ovoglycoprotein is glycosylated its detection might be obscured (Mann 2007). In summary, although several studies have shown that three lipocalin-like are present in egg white, their exact concentrations remain unclear. Therefore, their biological significance in egg white remains to be established.

Sequestration of bacterial siderophores

by the lipocalin-like Ex-FABP protein found in egg white

\section{Ex-FABP was first discovered as a fatty-acid-binding protein with a role in hen-embryo development}

Cancedda et al. (1988) were the first to report and identify Ex-FABP (Ch21) as a protein expressed and secreted by in vitro differentiating hen chondrocytes at a late stage of development. Ex-FABP was later shown to be a $21 \mathrm{kDa}$ protein in cartilage (Cancedda et al. 1988), muscle tissue (Gentili et al. 1998) and granulocytes (Dozin et al. 1992) of chicken embryos. This protein was classified as a member of the superfamily of lipocalins and thus was considered to have a likely role in the transport of small hydrophobic molecules (Cancedda et al. 1990). The protein was renamed (from CH21) 'extracellular fatty acid-binding protein' because of its ability to selectively bind and transport fatty acids (i.e. oleic, linoleic, and arachidonic acid) in extracellular fluids and serum (Cancedda et al. 1996). It was shown to be expressed during muscle-fibre formation (Gentili et al. 1998) and later shown to have involvement in endochondral-bone formation (Cermelli et al. 2000; Gentili et al. 2005). Transfection of proliferating chondrocytes and myoblasts with an expression vector expressing antisense Ex-FABP cDNA led to a decreased cell viability. Therefore, Ex-FABP seems to play a part in cell differentiation and cell survival (Di Marco et al. 2003; Gentili et al. 2005). It was more recently shown that Ex-FABP binds the $\mathrm{C} 16$ and $\mathrm{C} 18$ isoforms of lysophosphatidic acid (LPA, 1- or 2-acyl-sn-glycerol-3-phosphate) (Correnti et al. 2011). LPAs are phospholipids mediating differentiation, inflammation, immune function, oxidative stress, cell migration, smooth muscle contraction, apoptosis and development (Zhao and Natarajan 2014). It is likely that the functions of ExFABP reported above depend on its role in sensing or transporting phospholipids (Sia et al. 2013).

\section{Ex-FABP also binds siderophores and inhibits bacterial growth}

More recent reports indicate that Ex-FABP functions in pathogen defence through an ability to bind siderophores, in a manner analogous to that of LCN2 (Correnti et al. 2011; Garénaux et al. 2013). This suggests that Ex-FABP may have two distinct purposes, one in fatty acid/LPA binding and another as a siderophore-binding factor. Work of Correnti et al. (2011) shows that Ex-FABP sequesters ferric-enterobactin, as well as its mono-glucosylated (Fe-MGEnt) form with a $\mathrm{K}_{\mathrm{d}}$ of 0.22 and $0.07 \mathrm{nM}$, respectively; but not its di-glucosylated form (Fe-DGEnt; $\mathrm{K}_{\mathrm{d}}$ $>600 \mathrm{nM}$ ). Furthermore, Ex-FABP at $5 \mu \mathrm{M}$ caused growth inhibition of both E. coli and Bacillus subtilis under iron-limited in vitro conditions. Growth was restored by supplementing the cultures with stoichiometric amounts of $\mathrm{FeCl}_{3}$ (Correnti et al. 2011). Thus, Ex-FABP might act to reduce bacterial growth in egg white by enhancing iron restriction (Fig. 3). Ex-FABP did not inhibit Pseudomonas aeruginosa growth under iron limitation, which correlates with the observation that Ex-FABP does not bind the corresponding siderophores. Indeed, both enterobactin and bacillibactin produced by E. coli and B. subtilis (respectively) were found to be sequestrated by Ex-FABP $\left(K_{d}\right.$ of 0.5 and $30 \mathrm{nM}$, respectively), while pyochelin and pyoverdine produced by $P$. aeruginosa were not (Correnti et al. 2011). These findings are also in accordance with those from Garénaux et al. (2013) showing that E. coli $\mathrm{K}-12$ is subject to a $10^{5}$-fold growth reduction when exposed to $2.5 \mu \mathrm{M}$ Ex-FABP or LCN2. However, when transformed with a plasmid harbouring the iroBCDEN cluster, no growth defect was observed by $2.5 \mu \mathrm{M}$ Ex-FABP or LCN2. Exposure of six poultry APEC isolates to $2.5 \mu \mathrm{M}$ Ex-FABP or LCN2 inhibited the growth of strains producing enterobactin as sole siderophore, but not those producing additional siderophores (salmochelin, aerobactin and/or yersinabactin) (Garénaux et al. 2013). Therefore, it can be concluded that Ex-FABP is an avian siderocalin-type lipocalin with a function similar to that of LCN2. 


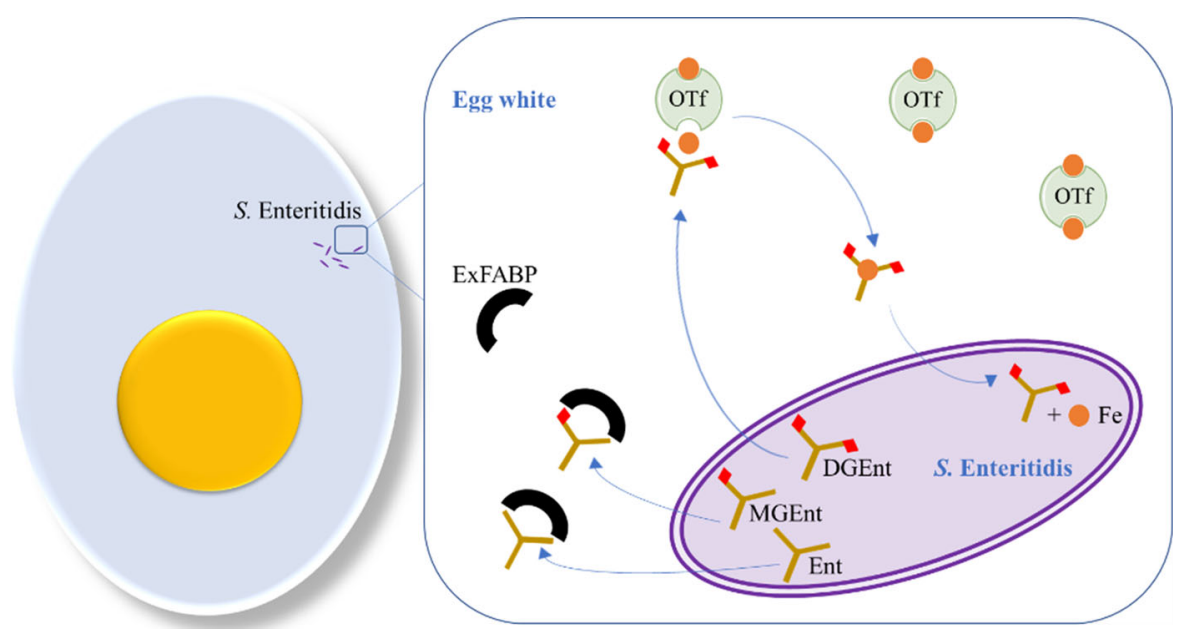

Fig. 3 Potential interactions between SE siderophores and ExFABP. In the egg white, enterobactin (Ent) and MGEnt might be sequestrated by Ex-FABP (represented by black semi-circles), while DGEnt would remain free to chelate iron from

The pleiotropic function (i.e. siderophore and LPA binding) of Ex-FABP might be explained by the large binding site of the molecule (Sia et al. 2013). ExFABP has a three-dimensional fold common to that of lipocalin family proteins but has an extra $\alpha$-helix (residues 22-30) and short helical element (residues 139-141). This results in an extended calyx that encompasses upper and lower cavities (Fig. 4). The upper cavity comprises a siderophore-binding site with three catechol-binding pockets involving basic residues (K82, R101 and R112) key to ligand binding (Correnti et al. 2011). K82 forms hydrogen bonds with the 3-OH of the catechol groups, while R101 and R112 provide significant electrostatic contributions to ligand-binding. The lower cavity acts as a hydrophobic binding site that can bind $\mathrm{C} 16$ and C18 LPA. Modelling of the complex shows that the side-chains Y50, K82, R112 and Y114 of Ex-FABP make hydrogen bonds with LPA (Correnti et al. 2011).

The other lipocalins of egg white

\section{Phylogenic relationship}

A multiple-sequence alignment and phylogenetic analysis of the three lipocalin-like proteins of egg white is presented in Figs. 5 and 6. The tree can be organised into three lobes, as described by Flower et al. (2000): proteins in the green lobe include ovotransferrin (OTf indicated as green) and thus provide iron to $\mathrm{SE}$ (glucosyl groups are shown as red diamonds). After import into the cytoplasm, $\mathrm{Fe}^{3+}$ (drawn as orange circles) is finally released into the cytoplasm

prostaglandin D synthase (PTGDS), neutrophil lipocalin and $\alpha$-1-microglobulin $(\alpha 1 \mathrm{M})$; the blue lobe includes bilin-binding protein (BBP), retinol-binding protein (RBP) and apolipoprotein $\mathrm{D}(\mathrm{apoD})$; and the orange lobe is formed of major-urinary protein (MUP) and $\beta$-lactoglobulin $(\beta-\lg )$. This phylogenetic analysis indicates that both $\mathrm{Cal}-\gamma$ and $\alpha-1$-ovoglycoprotein have a human orthologue. This is in accordance with a comparative analysis of the chicken genome that showed that $60 \%$ of chicken protein-coding genes have a single human orthologue (Consortium ICGS 2004). This tree also indicates that LCN2 from $H$. sapiens is more closely related to $\mathrm{Cal}-\gamma$ than to the other two lipocalin-like proteins found in chicken egg white, and that $\alpha$-1-ovoglycoprotein could be considered as an outlier among the lipocalin family. Yet, despite their limited sequence identities (26\%; NCBI 2019), hen Ex-FABP and human LCN2 have similar ligand-binding affinities (Correnti et al. 2011). According to Fig. 6, there is a close homologue of known function to Ex-FABP found in quail: the Q83 lipocalin (88\% identity; NCBI 2019). Q83 was originally identified based on its overexpression in quail embryo fibroblasts transformed with the v-myc oncogene. Q83 sequesters enterobactin with a mode of binding equivalent to that of LCN2 (Coudevylle et al. 2010). This resembles Ex-FABP's function, as described above, in siderophore inhibition, and is consistent with its presence in egg white. Surprisingly, 


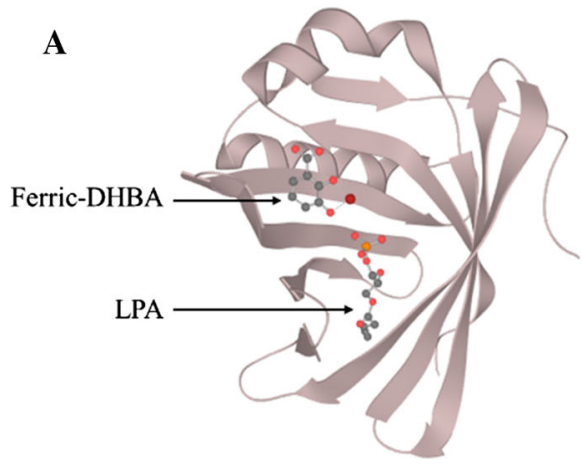

Fig. 4 a X-ray diffraction (1.8 ̊ resolution) of Ex-FABP; two ligands are represented, ferric-DHB in the upper cavity and LPA in the lower cavity. Structure extracted from Protein Data
B

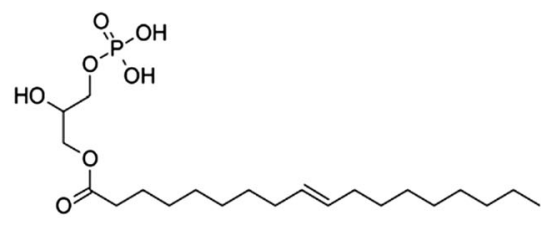

Bank (PMID: 22153502; Correnti et al. 2011). b Structure of a C18 lysophosphatidic acid (LPA)

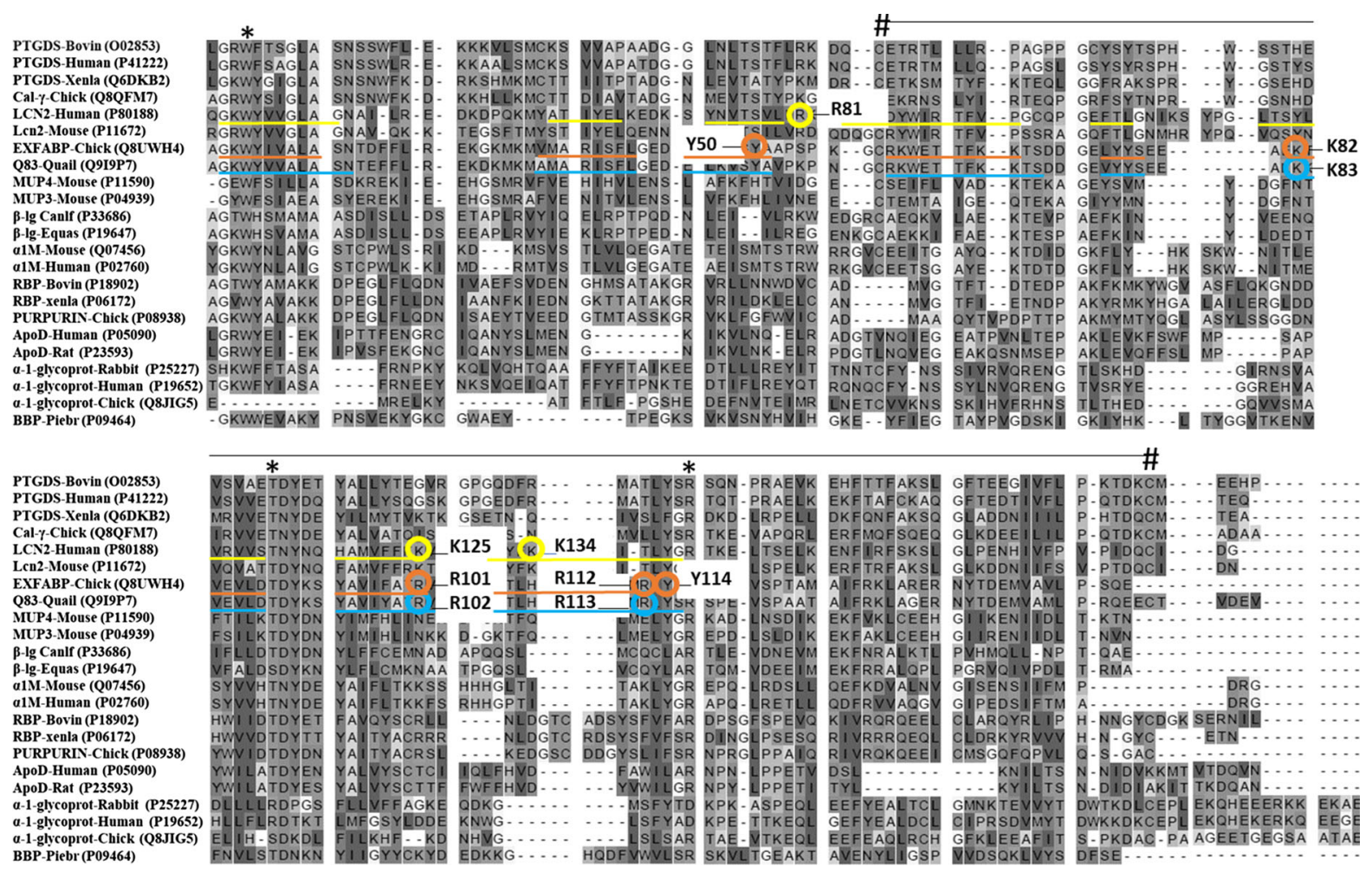

Fig. 5 Multiple-sequence alignment (Genomic Workbench) of lipocalin-like proteins found in egg white with their closest homologues extracted from the Pfam database (El-Gebali et al. 2019) and NCBI (2019). The Uniprot accession number of each protein is in brackets. Three motifs are shown (*) centred on the conserved tryptophan, threonine and arginine residues. These residues are preserved in lipocalins and seal the bottom end of

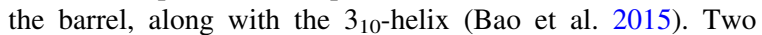
cysteine residues (\#) playing a role in disulphide bridging are

there is no close homologue of Ex-FABP in man, nor of LCN2 in chicken: the closest human homologue of also conserved. Residues (putatively) involved in siderophore binding are circled in yellow for LCN2: R81, K125, K134 (Goetz et al. 2002) and blue for Q83: K83, R102, R113 (Coudevylle et al. 2010). For Ex-FABP, residues involved in siderophore (K82, R101, R112) and LPA (Y50, K82, R112, Y114) binding are circled in orange. The $\beta$-strands of the eightstranded $\beta$-barrel of the LCN2, Q83 and Ex-FABP are underlined in yellow, orange and blue, respectively

Ex-FABP is lipocalin 15 and the closest chicken homologue of LCN2 is Cal- $\gamma$ ( 28 and $30 \%$ amino-acid 


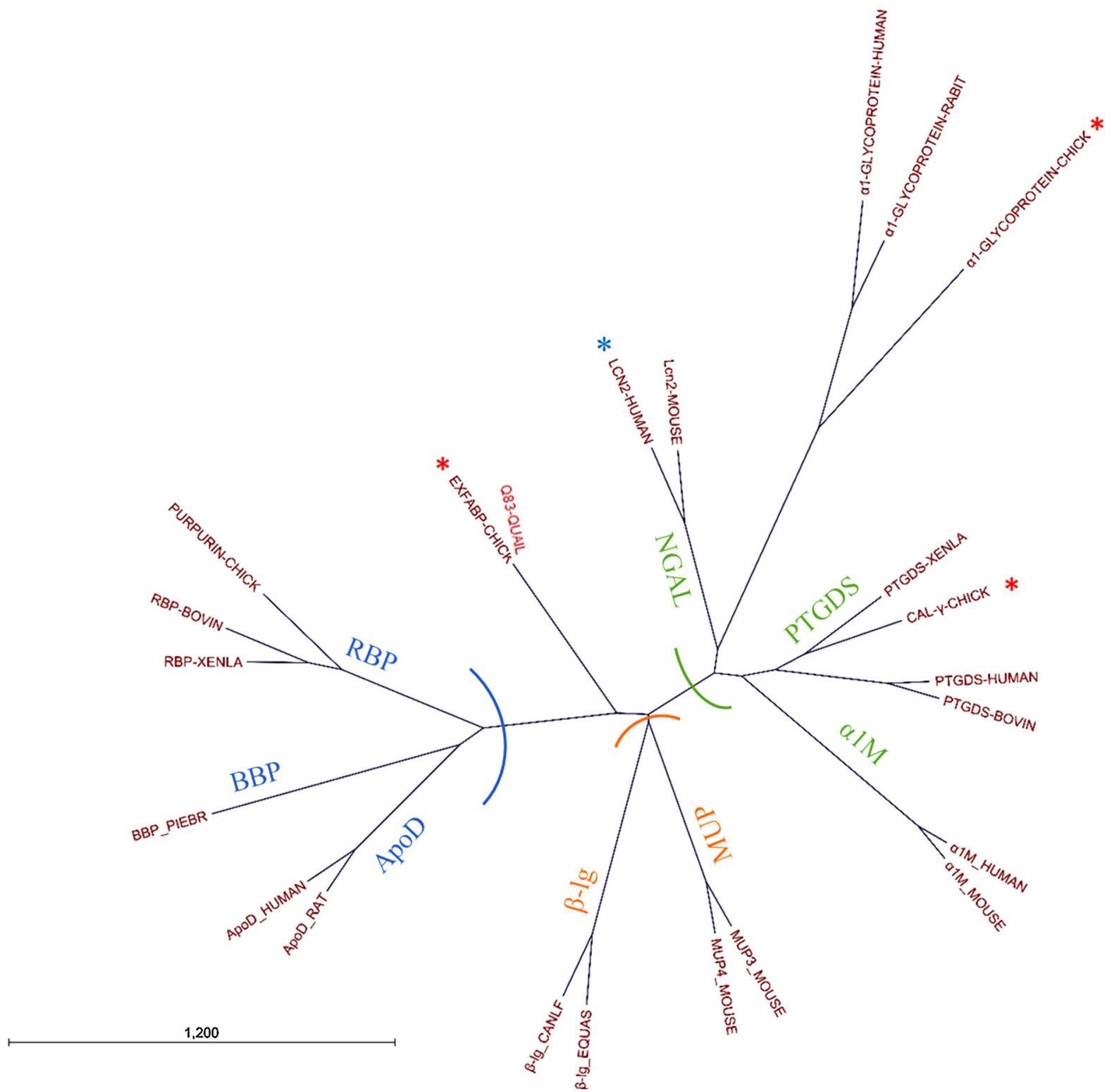

Fig. 6 Neighbour-joining tree of the lipocalin-like proteins found in egg white and their closest homologues. The alignment of lipocalin-like proteins (Fig. 5) extracted from the Pfam family PF00061 and NCBI (2019) was used to build the phylogeny tree with CLC Genomics Workbench (protein

sequence identity, respectively; NCBI 2019). This suggests that the siderophore-binding activities of these two proteins have evolved independently, in related proteins, in order to fulfil similar functional requirements in innate immunity. distance was estimated from the Jukes-Cantor model). Three lobes are identified with coloured half-circles (green for NGAL, PTGDS and $\alpha 1 \mathrm{M}$; orange for $\beta-\lg$ and MUP; blue for RBP, BBP and ApoD). Red stars show the lipocalin homologues found in hen egg white. The blue star indicates human lipocalin-2

\section{Alpha-1-ovoglycoprotein and Cal- $\gamma$ : their potential functions in egg white}

Alpha-1-ovoglycoprotein (or 'orosomucoid') shares a closely-related common ancestor with other $\alpha 1$-acid glycoproteins found in various animals (Fig. 6). Despite its induction as an acute-phase protein, and 
its role in cellular inflammation and transport of drugs in human serum, its biological purpose is unclear (Huang and Ung 2013). In man, this protein is found in the serum where it is heavily glycosylated and highly acidic due to the presence of sialic acid. Human $\alpha 1$ acid-glycoprotein ( $\alpha 1$-AGP) is a highly glycosylated protein (approximatively 45\%) of $43 \mathrm{kDa}$ with a pI of 2.7 (Schmid 1975). There are at least two genes encoding $\alpha 1$-AGP identified, thus it has been suggested that the protein found in plasma is a mixture of the products of these two distinct genes (Dente et al. 1985). The normal plasma concentration in man is between 0.7 and $1.0 \mathrm{~g} / \mathrm{L}$. However, as an acute-phase protein, its concentration can increase to $3 \mathrm{~g} / \mathrm{L}$ under inflammatory conditions (Kremer et al. 1988). It is known to bind lipopolysaccharide and can stimulate the activation of inflammatory cell lines (Boutten et al. 1992). Interestingly, $\alpha 1$-AGP has a protective effect in a mouse meningococcal shock model, suggesting a potential antibacterial role (Moore et al. 1997). In egg white, the $\alpha$-1-ovoglycoprotein has an average molecular weight of $30 \mathrm{kDa}$, an isoelectric point of 4.37-4.51 and a sugar content of about 25\% (Matsunaga et al. 2004). While little is known about its function, this ovoglycoprotein is often used for its chiral properties to separate drug enantiomers (Sadakane et al. 2002; Haginaka and Takehira 1997). However, its biochemical, functional and biological properties in egg white remain unknown.

The phylogenetic analysis (Fig. 6) indicates that the closest homologue of $\mathrm{Cal}-\gamma$ is lipocalin-like prostaglandin synthase (PTGDS). In mammals, PTGDS is secreted into various body fluids. This protein catalyses the isomerization of prostaglandin $\mathrm{H} 2$ to prostaglandin $\mathrm{D} 2$, and was reported to bind a variety of lipophilic molecules such as biliverdin, bilirubin and retinoic acid. In humans, this protein is likely to be involved in both maturation and maintenance of the central-nervous system and male reproductive system (Saito et al. 2002; Urade and Hayaishi 2000). Two isoforms, of $22 \mathrm{kDa}$, can be separated by 2D-electrophoresis of egg white, thanks to their different isoelectric points ( $\mathrm{pI}$ of 5.6 and 6.0) (Guérin-Dubiard et al. 2006). Pagano et al. (2003) have shown that $\mathrm{Cal}-\gamma$ expression correlates with endochondral bone formation and the inflammatory response. As for Ex-FABP, Cal- $\gamma$ mRNA is increasingly synthesized during chondrocyte differentiation both in vivo and in vitro. Although Ex-FABP and Cal- $\gamma$ may both play a part in bone formation and the inflammatory response, any possible role for $\mathrm{Cal}-\gamma$ in siderophore sequestration remains to be explored.

\section{Conclusion}

The antibacterial iron-restriction activity of egg white, as mediated by oTf, is well established and it is now apparent that the egg-white lipocalin, Ex-FABP, can inhibit bacterial growth via an enhanced iron-restriction effect that is mediated by its siderophore-binding capacity. However, the siderophore-sequestering activity of Ex-FABP has neither been studied in egg white, nor with appropriate $S E$ or hen infection models. Furthermore, how and in what quantity this protein is incorporated into egg white remains unknown. As yet, it is unclear whether the other lipocalins of egg white (Cal- $\gamma$ and $\alpha$-1-glycoprotein) might also sequester siderophores. Although many egg-white proteins have been shown to be components of the arsenal of defence factors within egg white, the contribution (if any) of the three lipocalins as new eggwhite defence factors remains an open question, although this now appears highly likely for Ex-FABP. As matters stand, it is unclear whether the capacity of salmochelin to assists $S E$ virulence in mammalian models can be extended to include support of $S E$ survival in egg white. Thus, there remains much scope for further understanding of the role of lipocalin proteins in the defence of egg white against bacteria.

Acknowledgements This work was supported by the Strategic Fund of the University of Reading (UK) and the Regional Council of Britanny (allocations de recherche doctorale, ARED; France).

Open Access This article is distributed under the terms of the Creative Commons Attribution 4.0 International License (http:// creativecommons.org/licenses/by/4.0/), which permits unrestricted use, distribution, and reproduction in any medium, provided you give appropriate credit to the original author(s) and the source, provide a link to the Creative Commons license, and indicate if changes were made.

\section{References}

Aguilera O, Quiros LM, Fierro JF (2003) Transferrins selectively cause ion efflux through bacterial and artificial membranes. FEBS Lett 548:5-10 
Alderton G, Ward WH, Fevold HL (1946) Identification of the bacteria-inhibiting iron-binding protein of egg-white as conalbumin. Arch Biochem Biophys 11:9-13

Andrews SC, Robinson AK, Rodríguez-Quiñones F (2003) Bacterial iron homeostasis. FEMS Microbiol Rev 27:215-237

Antonini E, Orsi N, Valenti P (1977) Effetto delle transferrine sulla patogenicita delle Enterobacteriaceae. G Mal Infett Parassit 29:481-489

Bachman MA, Lenio S, Schmidt L, Oyler JE, Weiser JN (2012) Interaction of lipocalin 2, transferrin, and siderophores determines the replicative niche of Klebsiella pneumoniae during pneumonia. MBio 3:1-8

Banks JG, Board RG, Sparks NH (1986) Natural antimicrobial systems and their potential in food preservation of the future. Biotechnol Appl Biochem 8:103-147

Bao GH, Ho CT, Barasch J (2015) The Ligands of neutrophil gelatinase-associated lipocalin. RSC Adv 5:104363-104374

Baron F, Gautier M, Brule G (1997) Factors involved in the inhibition of growth of Salmonella Enteritidis in liquid egg white. J Food Prod 60:1318-1323

Baron F, Fauvel S, Gautier G (2000) Behaviour of Salmonella Enteritidis in industrial egg white: Egg naturally contains factors inhibitory to salmonella growth. In: Sim J, Nakai N, Guenter W (eds) Egg nutrition and biotechnology. CAB International, Oxon, pp 417-430

Baron F, Nau F, Guérin-Dubiard C, Bonnassie S, Gautier M, Andrews SC, Jan S (2016) Egg white versus Salmonella Enteritidis! A harsh medium meets a resilient pathogen. Food Microbiol 53:82-93

Baron F, Bonnassie S, Alabdeh M, Cochet MF, Nau F, GuérinDubiard C, Gautier M, Andrews SC, Jan S (2017) Global gene-expression analysis of the response of Salmonella Enteritidis to egg white exposure reveals multiple egg white-imposed stress responses. Front Microbiol 8:1-26

Bäumler AJ, Norris TL, Lasco T, Voigt W, Reissbrodt R, Rabsch W, Heffron F (1998) IroN, a novel outer membrane siderophore receptor characteristic of Salmonella enterica. J Bacteriol 180:1446-1453

Benjamin WH, Turnbough CL, Posey BS, Briles DE (1985) The ability of Salmonella Typhimurium to produce the siderophore enterobactin is not a virulence factor in mouse typhoid. Infect Immun 50:392-397

Bister B, Bischoff D, Nicholson GJ, Valdebenito M, Schneider K, Winkelmann G, Hantke K, Süssmuth RD (2004) The structure of salmochelins: C-glucosylated enterobactins of Salmonella enterica. Biometals 17:471-481

Bleuel C, Grosse C, Taudte N, Scherer J, Wesenberg D, Krauss GJ, Nies DH, Grass G (2005) TolC is involved in enterobactin efflux across the outer membrane of Escherichia coli. J Bacteriol 187:6701-6707

Boutten A, Dehoux M, Deschenes M, Rouzeau JD, Bories PN, Durand G (1992) $\alpha_{1}$-Acid glycoprotein potentiates lipopolysaccharide-induced secretion of interleukin-1 $\beta$, interleukin-6 and tumor necrosis factor- $\alpha$ by human monocytes and alveolar and peritoneal macrophages. Eur J Immunol 22:2687-2695

Bullen JJ, Rogers HJ, Griffiths E (1978) Role of iron in bacterial infection. Curr Top Microbiol Immunol 80:1-35
Bullen JJ, Rogers HJ, Spalding PB, Ward CG (2005) Iron and infection, the heart of the matter. FEMS Immunol Med Microbiol 43:325-330

Cancedda FD, Manduca P, Tacchetti C, Fossa P, Quarto R, Cancedda R (1988) Developmentally regulated synthesis of a low molecular weight protein (Ch 21) by differentiating chondrocytes. J Cell Biol 107:2455-2463

Cancedda FD, Dozin B, Rossi F, Molina F, Cancedda R, Negri A, Ronchi S (1990) The Ch21 protein, developmentally regulated in chick embryo, belongs to the superfamily of lipophilic molecule carrier proteins. J Biol Chem 265:19060-19064

Cancedda FD, Malpeli M, Gentili C, Di Marzo V, Bet P, Carlevaro M, Cermelli S, Cancedda R (1996) The developmentally regulated avian $\mathrm{Ch} 21$ lipocalin is an extracellular fatty acid-binding protein. J Biol Chem 271:20163-20169

Carpenter C, Payne SM (2014) Response to oxygen and iron availability. J Inorg Biochem 133:110-117

Caza M, Lépine F, Milot S, Dozois CM (2008) Specific roles of the iroBCDEN genes in virulence of an avian pathogenic Escherichia coli $\mathrm{O} 78$ strain and in production of salmochelins. Infect Immun 76:3539-3549

Cermelli S, Zerega B, Carlevaro M, Gentili C, Thorp B, Farquharson C, Cancedda R, Cancedda FD (2000) Extracellular fatty acid binding protein (Ex-FABP) modulation by inflammatory agents: 'physiological' acute phase response in endochondrol bone formation. Eur $\mathrm{J}$ Cell Biol 79:155-164

Chart H (1993) Iron restriction and the growth of Salmonella Enteritidis. Epidemiol Infect 110:41-47

Chenault SS, Earhart CF (1992) Identification of hydrophobic proteins FepD and FepG of the Escherichia coli ferrienterobactin permease. J Gen Microbiol 138:2167-2171

Clavijo RI, Loui C, Andersen GL, Riley LW, Lu S (2006) Identification of genes associated with survival of Salmonella enterica serovar Enteritidis in chicken egg albumen. Appl Environ Microbiol 72:1055-1064

Consortium ICGS (2004) Sequence and comparative analysis of the chicken genome provide unique perspectives on vertebrate evolution. Nature 432:695-777

Correnti C, Clifton MC, Abergel RJ, Allred B, Hoette TM, Ruiz M, Cancedda R, Raymond KN, Cancedda FD, Strong RK (2011) Galline Ex-FABP is an antibacterial siderocalin and a lysophosphatidic acid sensor functioning through dual ligand specificities. Structure 19:1796-1806

Coudevylle N, Geist L, Hötzinger M, Hartl M, Kontaxis G, Bister K, Konrat R (2010) The v-myc-induced Q83 lipocalin is a siderocalin. J Biol Chem 285:41646-41652

Crouch ML, Castor M, Karlinsey JE, Kalhorn T, Fang FC (2008) Biosynthesis and IroC-dependent export of the siderophore salmochelin are essential for virulence of Salmonella enterica serovar Typhimurium. Mol Microbiol 67:971-983

D’Ambrosio C, Arena S, Scaloni A, Guerrier L, Boschetti E, Mendieta ME, Citterio A, Righetti PG (2008) Exploring the chicken egg white proteome with combinatorial peptide ligand libraries. J Proteome Res 7:3461-3474

Demir M, Kaleli I (2004) Production by Escherichia coli isolates of siderophore and other virulence factors and their pathogenic role in a cutaneous infection model. Clin Microbiol Infect 10:1011-1014 
Dente L, Ciliberto G, Cortese R (1985) Structure of the human alpha 1-acid glycoprotein gene: sequence homology with other human acute phase protein genes. Nucleic Acids Res 13:3941-3952

Derde M, Lechevalier V, GuerinDubiard C, Cochet MF, Jan S, Baron F, Gautier M, Vié V, Nau F (2013) Hen egg white lysozyme permeabilizes the Escherichia coli outer and inner membranes. J Agric Food Chem 61:9922-9929

Desert C, Guerin-Dubiard C, Nau F, Jan G, Val F, Mallard J (2001) Comparison of different electrophoretic separations of hen egg white proteins. J Agric Food Chem 49:4553-4561

Devireddy LR, Gazin C, Zhu X, Green MR (2005) A cell-surface receptor for lipocalin $24 \mathrm{p} 3$ selectively mediates apoptosis and iron uptake. Cell 123:1293-1305

Di Marco E, Sessarego N, Zerega B, Cancedda R, Cancedda FD (2003) Inhibition of cell proliferation and induction of apoptosis by Ex-FABP gene targeting. J Cell Physiol 196:464-473

Dozin B, Cancedda FD, Briata L, Hayashi M, Gentili C, Hayashi K, Quarto R, Cancedda R (1992) Expression, regulation, and tissue distribution of the $\mathrm{Ch} 21$ protein during chicken embryogenesis. J Biol Chem 267:2979-2985

Du ZP, Wu BL, Wu X, Lin XH, Qiu XY, Zhan XF, Wang SH, Shen JH, Zheng CP, Wu ZY, Xu LY, Wang D, Li EM (2015) A systematic analysis of human lipocalin family and its expression in esophageal carcinoma. Sci Rep 5:1-14

EFSA Panel on Biological Hazards (2014) Scientific Opinion on the public health risks of table eggs due to deterioration and development of pathogens. EFSA J 12:1-147

El-Gebali S, Mistry J, Bateman A, Eddy SR, Luciani A, Potter SC, Qureshi M, Richardson LJ, Salazar GA, Smart A, Sonnhammer ELL, Hirsh L, Paladin L, Piovesan D, Tosatto SCE, Finn RD (2019) The Pfam protein families database. Nucleic Acids Res. https://doi.org/10.1093/nar/ gky995

Fischbach MA, Lin H, Zhou L, Yu Y, Abergel RJ, Liu DR, Raymond KN, Wanner BL, Strong RK, Walsh CT, Aderem A, Smith KD (2006) The pathogen-associated iroA gene cluster mediates bacterial evasion of lipocalin 2. Proc Natl Acad Sci USA 103:16502-16507

Flo TH, Smith KD, Sato S, Rodriguez DJ, Holmes MA, Strong RK, Akira S, Aderem A (2004) Lipocalin 2 mediates an innate immune response to bacterial infection by sequestrating iron. Nature 432:917-921

Flower DR (1996) The lipocalin protein family: structure and function. Biochem J 318:1-14

Flower DR, North ACT, Sansom CE (2000) The lipocalin protein family: structural and sequence overview. Biochim Biophys Acta-Protein Struct Mol Enzymol 1482:9-24

Françoise AM (1994) Lipocalines et transport de ligands hydrophobes. Med Sci 10:22-29

Furrer JL, Sanders DN, Hook-Barnard IG, McIntosh MA (2002) Export of the siderophore enterobactin in Escherichia coli: involvement of a $43 \mathrm{kDa}$ membrane exporter. Mol Microbiol 44:1225-1234

Gantois I, Eeckhaut V, Pasmans F, Haesebrouck F, Ducatelle R, Van Immerseel F (2008) A comparative study on the pathogenesis of egg contamination by different serotypes of Salmonella. Avian Pathol 37:399-406
Gao Q, Wang X, Xu H, Xu Y, Ling J, Zhang D, Gao S, Liu X (2012) Roles of iron acquisition systems in virulence of extraintestinal pathogenic Escherichia coli: salmochelin and aerobactin contribute more to virulence than heme in a chicken infection model. BMC Microbiol 12:143

Garénaux A, Houle S, Folch B, Dallaire G, Truesdell M, Lépine F, Doucet N, Dozois CM (2013) Avian lipocalin expression in chickens following Escherichia coli infection and inhibition of avian pathogenic Escherichia coli growth by ExFABP. Vet Immunol Immunopathol 152:156-167

Garibaldi JA (1970) Role of microbial iron transport compounds in bacterial spoilage of eggs. Appl Microbiol 20:558-560

Gehring AM, Mori I, Walsh CT (1998) Reconstitution and characterization of the Escherichia coli enterobactin synthetase from EntB, EntE, and EntF. Biochemistry 37:2648-26594

Gentili C, Cermelli S, Tacchetti C, Cossu G, Cancedda R, Cancedda FD (1998) Expression of the extracellular fatty acid binding protein (Ex-FABP) during muscle fiber formation in vivo and in vitro. Exp Cell Res 242:410-418

Gentili C, Tutolo G, Zerega B, Di Marco E, Cancedda R, Cancedda FD (2005) Acute phase lipocalin Ex-FABP is involved in heart development and cell survival. J Cell Physiol 202:683-689

Goetz DH, Willie ST, Armen RS, Bratt T, Borregaard N, Strong RK (2000) Ligand preference inferred from the structure of neutrophil gelatinase associated lipocalin. Biochemistry 39:1935-1941

Goetz DH, Holmes MA, Borregaard N, Bluhm ME, Raymond KN, Strong RK (2002) The neutrophil lipocalin NGAL is a bacteriostatic agent that interferes with siderophore-mediated iron acquisition. Mol Cell 10:1033-1043

Gong DQ, Wilson PW, Bain MM, McDade K, Kalina J, HerveGrepinet V, Nys Y, Dunn IC (2010) Gallin; an antimicrobial peptide member of a new avian defensin family, the ovodefensins, has been subject to recent gene duplication. BMC Immunol 11:1-15

Greene LH, Hamada D, Eyles SJ, Brew K (2003) Conserved signature proposed for folding in the lipocalin superfamily. FEBS Lett 553:39-44

Guérin-Dubiard C, Pasco M, Mollé D, Désert C, Croguennec T, Nau F (2006) Proteomic analysis of hen egg white. J Agric Food Chem 54:3901-3910

Guha-Thakurta P, Choudhury D, Dasgupta R, Dattagupta JK (2003) Structure of diferric hen serum transferrin at $2.8 \mathrm{~A}$ resolution. Acta Crystallogr D Biol Crystallogr 59:1773-1781

Haginaka J, Takehira H (1997) Separation of enantiomers on a chiral stationary phase based on ovoglycoprotein. J Chromatogr A 777:241-247

Hantke K, Nicholson G, Rabsch W, Winkelmann G (2003) Salmochelins, siderophores of Salmonella enterica and uropathogenic Escherichia coli strains, are recognized by the outer membrane receptor IroN. Proc Natl Acad Sci USA 100:3677-3682

Hervé-Grépinet V, Réhault-Godbert S, Labas V, Magallon T, Derache C, Lavergne M, Gautron J, Lalmanach AC, Nys Y (2010) Purification and characterization of avian $\beta$-defensin 11, an antimicrobial peptide of the hen egg. Antimicrob Agents Chemother 54:4401-4408 
Holmes MA, Paulsene W, Jide X, Ratledge C, Strong RK (2005) Siderocalin (Lcn 2) also binds carboxymycobactins, potentially defending against mycobacterial infections through iron sequestration. Structure 13:29-41

Huang Z, Ung T (2013) Effect of alpha-1-acid glycoprotein binding on pharmacokinetics and pharmacodynamics. Curr Drug Metab 14:226-238

Ibrahim HR (1997) Insights into the structure-function relationships of ovalbumin, ovotransferrin, and lysozyme. In: Yamamoto T, Juneja LR, Hatta H, Kim M (eds) Hen eggs their basic and applied science. CRC Press, New York, pp 37-56

Ibrahim HR, Iwamori E, Sugimoto Y, Aoki T (1998) Identification of a distinct antibacterial domain within the N-lobe of ovotransferrin. Biochim Biophys Acta-Mol Cell Res 1401:289-303

Ibrahim HR, Sugimoto Y, Aoki T (2000) Ovotransferrin antimicrobial peptide (OTAP-92) kills bacteria through a membrane damage mechanism. Biochim Biophys ActaGen Subj 1523:196-205

Kang H, Loui C, Clavijo RI, Riley LW, Lu S (2006) Survival characteristics of Salmonella enterica serovar Enteritidis in chicken egg albumen. Epidemiol Infect 134:967-976

Kjeldsen L, Johnsen AH, Sengeløv H, Borregaard N (1993) Isolation and primary structure of NGAL, a novel protein associated with human neutrophil gelatinase. J Biol Chem 268:10425-10432

Konopka K, Neilands JB (1984) Effect of serum albumin on siderophore-mediated utilization of transferrin iron. Biochemistry 23:2122-2127

Konopka K, Bindereif A, Neilands JB (1982) Aerobactin mediated utilization of transferrin iron. Biochemistry 24:6503-6508

Kovacs-Nolan J, Phillips M, Mine Y (2005) Advances in the value of eggs and egg components for human health. J Agric Food Chem 53:8421-8431

Kremer JM, Wilting J, Janssen LH (1988) Drug binding to human alpha-1-acid glycoprotein in health and disease. Pharmacol Rev 40:1-47

Lang ER, Rha C (1982) Apparent shear viscosity of native egg white. J Fd Technol 17:595-606

Langman L, Young IG, Frost GE, Rosenberg H, Gibson F (1972) Enterochelin system of iron transport in Escherichia coli: mutations affecting ferric-enterochelin esterase. J Bacteriol 112:1142-1149

Lin LN, Mason AB, Woodworth RC, Brandts JF (1994) Calorimetric studies of serum transferrin and ovotransferrin. Estimates of domain interactions, and study of the kinetic complexities of ferric ion binding. Biochem 33:1881-1888

Lin H, Fischbach MA, Liu DR, Walsh CT (2005) In vitro characterization of salmochelin and enterobactin trilactone hydrolases IroD, IroE, and Fes. J Am Chem Soc 127:11075-11084

Lock JL, Board RG (1992) Persistence of contamination of hens' egg albumen in vitro with Salmonella serotypes. Epidemiol Infect 108:389-396

Luo M, Lin H, Fischbach MA, Liu DR, Walsh CT, Groves JT (2006) Enzymatic tailoring of enterobactin alters membrane partitioning and iron acquisition. ACS Chem Biol $1: 29-32$
Mann K (2007) The chicken egg white proteome. Proteomics 7:3558-3568

Mann K, Mann M (2011) In-depth analysis of the chicken egg white proteome using an LTQ Orbitrap Velos. Proteome Sci 9:1-6

Matsunaga H, Sadakane Y, Haginaka J (2004) Identification of disulfide bonds and site-specific glycosylation in chicken? 1-acid glycoprotein by matrix-assisted laser desorption ionization time-of-flight mass spectrometry. Anal Biochem 331:358-363

Montgomerie JZ, Bindereif A, Neilands JB, Kalmanson GM, Guze LB (1984) Association of hydroxamate siderophore (aerobactin) with Escherichia coli isolated from patients with bacteremia. Infect Immun 46:835-838

Moore DF, Rosenfeld MR, Gribbon PM, Winlove CP, Tsai CM (1997) Alpha-1 acid glycoprotein (orosomucoid): interaction with bacterial lipopolysaccharide and protection from sepsis. Inflammation 21:69-82

Nagase H, Harris ED, Woessner JF, Brew K (1983) Ovostatin: a novel proteinase inhibitor from chicken egg white. J Biol Chem 258:7481-7489

National Center for Biotechnology Information (2019). National Library of Medicine (US), National Center for Biotechnology Information. https://www.ncbi.nlm.nih. gov. Accessed 14 Jan 2019

Neilands JB (1981) Microbial iron compounds. Annu Rev Biochem 50:715-731

Nielsen BS, Borregaard N, Bundgaard JR, Timshel S, Sehested M, Kjeldsen L (1996) Induction of NGAL synthesis in epithelial cells of human colorectal neoplasia and inflammatory bowel diseases. Gut 38:414-420

Nys Y, Sauveur B (2004) Valeur nutritionnelle des oeufs. INRA Prod Anim 5:385-393

O'Brien IG, Gibson F (1970) The structure of enterochelin and related 2,3-dihydroxy-N-benzoylserine conjugates from Escherichia coli. Biochim Biophys Acta 215:393-402

O’Brien IG, Cox GB, Gibson F (1971) Enterochelin hydrolysis and iron metabolism in Escherichia coli. Biochim Biophys Acta 237:537-549

Pagano A, Crooijmans R, Groenen M, Randazzo N, Zerega B, Cancedda R, Dozin B (2003) A chondrogenesis-related lipocalin cluster includes a third new gene, CAL $\gamma$. Gene 305:185-194

Pollack JR, Neilands JB (1970) Enterobactin, an iron transport compound from Salmonella Typhimurium. Biochem Biophys Res Commun 38:989-992

Pollack JR, Ames BN, Neilands JB (1970) Iron transport in Salmonella Typhimurium: mutants blocked in the biosynthesis of enterobactin. J Bacteriol 104:635-639

Qin X, He S, Zhou X, Cheng X, Huang X, Wang Y, Wang S, Cui Y, Shi C, Shi X (2019) Quantitative proteomics reveals the crucial role of $\mathrm{YbgC}$ for Salmonella enterica serovar Enteritidis survival in egg white. Int $\mathbf{J}$ Food Microbiol 289:15-126

Rabsch W, Voigt W, Reissbrodt R, Tsolis RM, Bäumler AJ (1999) Salmonella typhimurium IroN and FepA proteins mediate uptake of enterobactin but differ in their specificity for other siderophores. J Bacteriol 181:3610-3612

Rabsch W, Methner U, Voigt W, Tscha H, Reissbrodt R, Williams PH (2003) Role of receptor proteins for enterobactin 
and 2, 3-dihydroxybenzoylserine in virulence of Salmonella enterica. Infect Immun 71:6953-6961

Raffatellu M, George MD, Akiyama Y et al (2009) Lipocalin-2 resistance confers an advantage to Salmonella enterica serotype typhimurium for growth and survival in the inflamed intestine. Cell Host Microbe 5:476-486

Réhault-Godbert S, Labas V, Helloin E, Hervé-Grépinet V, Slugocki C, Berges M, Bourin MC, Brionne A, Poirier JC, Gautron J, Coste F, Nys Y (2013) Ovalbumin-related protein $\mathrm{X}$ is a heparin-binding ov-serpin exhibiting antimicrobial activities. J Biol Chem 288:17285-17295

Sadakane Y, Matsunaga H, Nakagomi K, Hatanaka Y, Haginaka J (2002) Protein domain of chicken alpha(1)-acid glycoprotein is responsible for chiral recognition. Biochem Biophys Res Commun 295:587-590

Saito S, Tsuda H, Michimata T (2002) Prostaglandin D 2 and Reproduction. Am J Reprod Immunol 47:295-302

Sauveur B (1988) Structure, composition et valeur nutritionnelle de l'œuf. Reproduction des volailles et production d'œufs. INRA, Paris, pp 347-374

Schade A, Caroline L (1944) Raw hen egg white and therole of iron in growth inhibition of Shigella dysenteriae, Staphylococcus aureus, Escherichia coli and Saccharomyces cerevisiae. Science 100:14-15

Schmid K (1975) The plasma proteins (structure, function and genetic control). In: Putman FW (ed) Academic Press, New York, pp184-228

Schneider WR, Doetsch RN (1974) Effect of viscosity on bacterial motility. J Bacteriol 117:696-701

Schneider DJ, Roe AL, Mayer RJ, Que L (1984) Evidence for synergistic anion binding to iron in ovotransferrin complexes from resonance raman and extended X-ray absorption fine structure analysis. J Biol Chem 259:9699-9703

Sharp PF, Powell CK (1931) Increase in the $\mathrm{pH}$ of the white and yolk of hens' eggs. Ind Eng Chem 23:196-199

Sharp PF, Whitaker R (1927) The relation of the hydrogen ion concentration of egg white to its germicidal action. J Bacteriol 14:17-46

Sia AK, Allred BE, Raymond KN (2013) Siderocalins: siderophore binding proteins evolved for primary pathogen host defense. Curr Opin Chem Biol 17:150-157

Skare JT, Ahmer BMM, Seachord CL, Darveau RP, Postle K (1993) Energy transduction between membranes: tonB, a cytoplasmic membrane protein, can be chemically crosslinked in vivo to the outer membrane receptor FepA. J Biol Chem 268:16302-16308

Urade Y, Hayaishi O (2000) Biochemical, structural, genetic, physiological, and pathophysiological features of lipocalin-type prostaglandin D synthase. Biochim Biophys ActaProtein Struct Mol Enzymol 1482:259-271
USDA National Nutrient Database for Standard Reference, Release 23 (2010)

Valdebenito M, Crumbliss AL, Winkelmann G, Hantke K (2006) Environmental factors influence the production of enterobactin, salmochelin, aerobactin, and yersiniabactin in Escherichia coli strain Nissle 1917. Int J Med Microbiol 296:513-520

Valdebenito M, Müller SI, Hantke K (2007) Special conditions allow binding of the siderophore salmochelin to siderocalin (NGAL-lipocalin). FEMS Microbiol Lett 277:182-187

Valenti P, De Stasio A, Mastromarino P, Seganti L, Sinibaldi L, Orsi N (1981) Influence of bicarbonate and citrate on the bacteriostatic action of ovotransferrin towards staphylococci. FEMS Microbiol Lett 10:77-79

Valenti P, Antonini GRH, Visca P, Orsi N, Antonini E (1983) Studies of the antimicrobial activity of ovotransferrin. Int J Tissue React 5:97-105

Valenti P, Visca P, Antonini G, Orsi N (1985) Antifungal activity of ovotransferrin towards genus Candida. Mycopathologia 89:169-175

Vylder JDE, Raspoet R, Dewulf J, Haesebrouck F, Ducatelle R, van Immerseel F (2013) Salmonella enteritidis is superior in egg white survival compared with other Salmonella serotypes. Poult Sci Assoc Inc 92:842-845

Watts RE, Totsika M, Challinor VL, Mabbett AN, Ulett GC, De Voss JJ, Schembri MA (2012) Contribution of siderophore systems to growth and urinary tract colonization of asymptomatic bacteriuria Escherichia coli. Infect Immun 80:333-344

Wesierska E, Saleh Y, Trzizka T, Kopec W, Siewinski M, Korzekwa L (2005) Antimicrobial activity of chicken egg white cystatin. World J Microbiol Biotechnol 21:59-64

Williams PH, Carbonetti NH (1986) Iron, siderophores, and the pursuit of virulence: independence of the aerobactin and enterochelin iron uptake systems in Escherichia coli. Infect Immun 51:942-947

Yadav NK, Vadehra DV (1977) Mechanism of egg white resistance to bacterial growth. J Food Sci 42:4-6

Zhao Y, Natarajan V (2014) Lysophophatidic acid (LPA) and its receptors: role in airway inflammation and remodeling. Biochim Biophys Acta 1831:86-92

Zhu M, Valdebenito M, Winkelmann G, Hantke K (2005) Functions of the siderophore esterases IroD and IroE in iron-salmochelin utilization. Microbiol 151:2363-2372

Publisher's Note Springer Nature remains neutral with regard to jurisdictional claims in published maps and institutional affiliations. 